\title{
С. Дудаков
}

\section{УАЬЯНОВ-АЕНИН. ШТРИХИ К ПОРТРЕТУ}

Дудаков, Савва - историк, публицист (Иерусалим).

В апреле 1917 г. Ленин прибывает на станцию Белоостров. Его встречает многочисленная делегация рабочих Сестрорецкого завода. На площади у Финляндского вокзала собралась многотысячная толпа, а у дворца Кшесинской - десятки тысяч. От вокзала до Кронверкского проспекта он двигался на броневике, и толпа народа возрастала в геометрической прогрессии. Это был триумф. Почему картавый человек стал оратором, превосходящим Керенского и Троцкого? Почему он одной лишь силой убеждения стал первым в русской социал-демократии? Почему Плеханов и Мартов - пасовали перед ним?

Одним террором большевики не могли удержаться у власти - это аксиома. Тогда чем? Лозунгами? Одних лозунгов недостаточно. Фигура Ленина стала цементом Новой России. Собственно - он сохранил русскую империю, уступив некоторые окраины. Даже удержал полуколонию Монголию и присоединил Бухарский эмират. Площадь России к 1897 г. составляла 22,35 млн км ${ }^{2}$. В 1905 г. Россия потерпела поражение в войне с Японией и уступила Южный Сахалин и прилегающие острова, всё, что ниже 50-й параллели, города Порт-Артур и Дальний на Ляоданском полуострове.

После Первой мировой войны, войны с Польшей, отделения Финляндии и Прибалтики, оккупации Румынией Бессарабии и добровольной отдачи Турции Карса территория будущего СССР уменьшилась до 21,7 млн км². Как видим, потери не столь значительные, если учесть масштаб катастрофы. За одно это - националисты должны быть благодарны Первому коммунисту.

Этот человек был способен признаваться в своих ошибках и заблуждениях. Думаю, что НЭП был рассчитан не на одно десятилетие. Отменить продразверстку еще в 1919 г. предлагал Троцкий. Ленин был категорически против. Поворот к НЭПу был произведен через год под грохот Кронштадтского восстания и в «атмосфере угрожающих настроений всей армии». А концессии 
двинули бы промышленный и социальный потенциал далеко вперед. Это не были бы кровавые сталинские пятилетки. Залогом того являлось то, что к 1926 г. потенциал России, уменьшившейся территориально, достиг уровня 1913 г. НЭП был направлен и против большинства партийных работников. Замечание И. Эренбурга: «Открывались новые пути и новые возможности. Нечеловеческая воля прозвучала в этом приглашении “учитесь торговать", брошенном бескорыстнейшим борцом своим товарищам, принужденным менять теперь диаграммы главков и карты Генштаба на стук костяшек или на книги двойной бухгалтерии. Трезвость, эта самая требовательная и, скажем откровенно, наименее заманчивая изо всех добродетелей, быстро вернула людям сознание времени и пространства». (Советская цензура вычеркнула эти слова из собрания сочинений Ильи Григорьевича, изданном в 1961 г.)

Кто первый разглядел в Ульянове Ленина? Сложно ответить на этот вопрос. Но одним из первых был Виктор Мандельберг (1869/70-1944), бывший член второй Государственной думы от социал-демократической фракции, меньшевик, с 1907 г. - в эмиграции. Он был делегатом II съезда РСДРП, где произошел раскол эсдеков на большевиков и меньшевиков. Со съезда делегаты понесли в Россию семена раздора. Отношения между двумя фракциями установились самые скверные. Дрязги, сплетни, усиление разногласий... Почему?

Вот ответ Мандельберга: «Потому, что причина, вызвавшая разногласия на съезде, именно - специфическое ленинское упрощенное... понимание задач партии и сущности революционной борьбы - не только оставалось, но, наоборот, благодаря расколу получило возможность выкристаллизироваться в последовательно проводимую систему... Чем сложнее задачи ставила всё стремительнее развивающаяся революция, тем, понятно, всё более и более ошибочные ответы должен был давать всё упрощающий ленинизм». ${ }^{1}$ Это потрясающее свидетельство. К тому же, кажется, впервые употреблено слово «ленинизм».

Взаимные выпады и обвинения эмигрантская среда выбрасывала на территорию империи, и лишь социальные низы могли стать электоратом нового движения. Кстати, первые оценки социал-демократов со стороны народовольцев были негативными. Конечно, на лицах выживших героев 70-80-х годов XIX в. можно было прочесть отпечаток мученичества и трагизма, и в оценке нового движения они были почти единогласны: «Мы» - народовольцы - «аристократы», а «вы» - социал-демократы - «плебс». В прошлом

1. Мандельберг В. Из пережитого. - Давос, 1910. - С. 41. 
народоволец и народоправец, позднее правый эсер Н. Тютчев высказался так: «Теперь в Сибирь улица пошла»².

Множество версий выдвигалось относительно происхождения псевдонима, который избрал Владимир Ульянов - ЛЕНИНЪ. Позволю себе изложить свою, пусть и причудливую, версию ${ }^{3}$. В Германии существует одно стихотворное пророчество на латинском языке, приписываемое монаху Герману, жившему в XIII в. Иногда называют «точную» дату появления пророчества 1300 г., но получило известность оно лишь в 1693 г. и многократно переиздавалось.

Пророчество называется - Vaticanium Lehniness (Лени́нское пророчество), названное по местечку Лени́н (ударение на последнем слоге), неподалеку от Потсдама, известное развалинами старинного цистерцианского монастыря Гиммельпфорт, основанного в 1180 г. (Цистерциане - монашеский орден, ветвь бенедиктинцев. В Польше их называют бернардинами.) Вероятно, пророчество фальшивка.

В этом подложном пророчестве, с одной стороны, оплакивается гибель дома Асканиев (им когда-то принадлежал Лени́н), а с другой - возвышение династии Гогенцоллернов, должное привести к объединению Германии. Предрекается и гибель последней династии в одиннадцатом поколении. Наследниками Асканийской династии были князья Ангальт-Цербстские. Иначе говоря, дом Романовых был тесно связан через Екатерину Великую с этой династией, ибо она была принцессой Ангальт-Цербстской. (Кстати, эта династия ведет свой род от славян - сербов. Отсюда - иербстская.) Возможно эти исторические изыскания смогут помочь в выяснении происхождения странного псевдонима.

Как бы то ни было, можно заметить, что в этом псевдопророчестве имеются антироялистские тенденции, которые, зная биографию Ульянова, могли сделать для него привлекательным этот псевдоним. Учтем, что впервые псевдоним «Ленинъ» появился в газете «Заря» в 1901 г. Том энциклопедического словаря Брокгауза и Ефрона со статьей о «Ленинском пророчестве» вышел в 1896 г. Так что версия имеет право на существование ${ }^{4}$.

2. Сергиевский Н. Ленин в ссылке // Красная летопись: Исторический журнал. - Л., 1924. - № 1 (10). - C. 15.

3. Я не первый, кому она пришла в голову. Думаю, что первыми были сотрудники института К. Маркса и Ф. Энгельса во времена директорства Давида Борисовича Рязанова (Гольдендаха) (1870-1938). Рязанов лично знал Ленина и вполне мог задать ему этот вопрос.

4. Статья о пророчестве имеется также в «Настольном энциклопедическом словаре» (M., 1892. T. IV). Издание А. Гербеля и Ко. Это как раз тот IV том, с которого начинается будущая энциклопедия братьев Гранат. Но вполне вероятно, что Ульянов мог быть знаком с «Ленинским пророчеством» и по немецким источникам. 
Добавим, что псевдоним «Ленин» использовался в артистическом мире в начале XX в.

Информативны воспоминания Владимира Александровича Поссе (18641940). Он был одним из самых интересных людей своего времени, публицистом, народником, марксистом и, по словам Л.Н. Толстого, принадлежал к лучшим образцам «интеллигенции» ${ }^{5}$. Являясь личным другом Горького, Поссе оказал на него и Ленина громадное влияние, хотя оба они отрицали это ${ }^{6}$.

Характеризуя Ленина и Плеханова, Поссе замечает: «Съезд партии - это турнир между социал-демократами и нарождающейся партией социалистовреволюционеров. Самый солидный теоретик первых был Плеханов, самый боевой теоретик и практик Ленин» ${ }^{7}$

Плеханов и Ленин - русские, и в наружности - русское, купеческое, но у каждого своеобразное. «Ленин, почти ровесник Чернова, казался в то время (т.е. в 1902 г.) значительно старше его, - продолжает Поссе, - а теперь, пожалуй, выглядит помоложе, ибо Ленин раньше Чернова и внешне, и внутренне установился. Уже тогда у него была очень солидная плешь, обнажавшая хорошо вылепленный череп с остатками рыжих волос. Лицо с сильно развитыми скулами, с рыжей бородкой - некрасиво, но вся суть в глазах, карих, умных, смеющихся и лукаво и ласково. Небольшого роста, коренастый, жилистый, с быстрыми уверенными жестами - он мог сойти за смышленого прасола, промышляющего скупкой у крестьян шерсти и льна» ${ }^{8}$.

Блестящий портрет, сделанный вовремя, в будущем он сошел бы за карикатуру. Еще неожиданнее отношение Поссе к Плеханову. «На подмогу Ленину под шумные аплодисменты поднимается на кафедру пожилой плешивый интеллигент с густыми черными бровями, мефистофельски загнутыми над живыми, во все стороны стреляющими глазами. Это был Плеханов. Говорит он с продуманной жестикуляцией, говорит красно, точнее пестро: так и сыплются остроты, цитаты, в том числе из Крылова, ссылки на героев Гоголя и Щедрина... Несмотря на это или именно поэтому, слушать его было жутко, ибо легкая шутливая форма особенно ярко оттеняла зловещую жестокость содержания. Нападая на террор социалистов-революционеров, он восхвалял

5. Толстой Л. Дневник, 24 июля 1909 г. // Толстой Л.Н. Полн. собр. соч. - М.: Художественная литература, 1952. - Т. 58. - С. 101.

6. Горький М. Из литературного наследия // Горький и еврейский вопрос. - Иерусалим: Еврейский университет в Иерусалиме, Центр по исследованию и документации восточноевропейского еврейства, 1986 / Сост. М. Агурский и М. Шкловская. Примечание на с. 90.

7. Поссе В. Воспоминания (1905-1917). - Пг.: Мысль, 1923. - С. 88.

8. Там же. - C. 89. 
террор Великой французской революции, террор Робеспьера. Каждый социалдемократ, говорит Плеханов, должен быть террористом, а'lа Робеспьер. Мы не станем, подобно социалистам-революционерам, стрелять в царя и его прислужников, по после победы мы воздвигнем для них гильотину на Казанской площади. Не успел он закончить этой фразы, когда среди жуткой тишины, переполненной залы раздался отчетливый голос: “Какая гадость!” Сказано это было громко, но спокойно, убежденно и потому внушительно, Плеханов побелел, вернее, посерел...»"

На следующий день Поссе написал резкое письмо Плеханову о разрыве с ним, Лениным и другими, и печатно стал выступать против тогдашней социал-демократии. Обратим внимание, что в 1923 г. Поссе имел мужество отвергать классовый террор, прозрачно намекая на советский режим: «Обещание поставить гильотину на Казанской площади стоит в тесной связи с обещаниями, данными Плехановым и его сторонниками на съезде РСДРП в 1903 г., разогнать русский парламент через две недели, если состав его будет не соответствовать интересам Социал-Демократической Партии, или, напротив, сделать его бессрочным, если состав его будет этим интересам соответствовать, лишить буржуазию избирательных прав, ограничить свободу слова, не считаться с неприкосновенностью личности...»

Не надо быть особенно прозорливым, чтобы узреть под анонимными словами «его сторонников» истинных руководителей Октября, одним махом решивших проблему Учредительного собрания и прочих «мелочей»: свободы слова, свободы личности и т.д. Резюме о встрече с Плехановым и Лениным следующее: «Злость сильна, и на этот раз победа осталась за "искровцами", несмотря на гадость Плеханова» ${ }^{10}$.

И еще одна деталь. Думаю, она касается больше Ленина, чем царя: «Будь на месте Николая II человек с такими способностями и с такой могучей волей, какие были у Петра I, русская история конца XIX и начала XX века была бы несколько иной, чем мы ее теперь знаем. Совершенно отрицать роль личности в истории для тех, кому интересно общественное творчество Ленина, невозможно. И надо помнить, что в социологии, как в математике, приходится считаться с величинами не только положительными, но и отрицательными» ${ }^{11}$.

Среди причин возвышения Ленина следует отметить его несомненную «харизму». Обратимся к ранним воспоминаниям одного из первых соратников вождя, затем исчезнувшего в «никуда» (к счастью, он умер в своей постели). По его словам, он рано отошел от революционной деятельности

9. Поссе В. Воспоминания (1905-1917). - Пг.: Мысль, 1923. - С. 90-91.

10. Там же - С. 90-91, 93.

11. Там же. - C. 22-23. 
и потому со временем перестал существовать для Ленина. Речь идет об экономисте Михаиле Александровиче Сильвине (1874-1955). «Остановлюсь на некоторых личных свойствах Владимира Ильича. Как я уже сказал, мы единогласно, бесспорно и молчаливо признали его нашим лидером, нашей главой; это его главенство основывалось не только на его подавляющем авторитете как теоретика, на его огромных знаниях, необычной трудоспособности, на его умственном превосходстве - он имел для нас и огромный моральный авторитет... он импонировал нам также моральным величием. Нам казалось, [что] он был совершенен, свободен от тех мелких слабостей, которые можно найти в каждом» ${ }^{12}$.

В качестве примера его «харизмы» приводится встреча в Риге с латышскими социал-демократами, которые с предубеждением относились к россиянам. В течение трех дней общения с ними Владимир Ильич полностью очаровал латышей.

«Здесь еще раз убедился я, насколько этот человек был одарен способностью увлекать сердца, внушать к себе беспредельное доверие, наполнить чувством беззаветной преданности единой цели - всё это я не раз имел случай наблюдать и в отношении целых групп и отдельных лиц.

Бывали случаи, что человек достаточно зрелый, независимый в своем образе мыслей, в своих суждениях, образованный и опытный, которого никак нельзя упрекнуть в недостатке самостоятельности, после нескольких недель общения с Владимиром Ильичом совершенно подпадал под влияние его железной воли, его сильного ума...

В личных отношениях В.И. был обаятельный человек с большой выдержкой, деликатный, терпеливый к собеседнику - не всегда интересному, очень гостеприимный.

[Я] знал его позже в Сибири, во время ссылки, я видел его затем в эмиграции; и знаю, что, когда этот человек имел дело с теми, кого он считал врагами своей идеи, а стало быть, и своими личными, он был беспощаден. На мои сомнения в некоторых случаях, и с той насмешкой, которая часто смотрела из его глаз, замечал мне: “Революция - не игра в бирюльки”... “Для того чтобы она победила, нужно сосредоточить на ней всё внимание, всю свою энергию, все свои силы и всю волю, сосредоточить, отбрасывая всё лишнее, всё не идущее к цели". И эти, как иногда говорят, односторонность и исключительность, нетерпимость и беспощадность были ему свойственны».

Ссылаясь на слова самого Ильича, Сильвин напоминает, что «будущий вождь мирового пролетариата был исключен из Казанского университета,

12. Сильвин М.А. К биографии В.И. Ленина. Из воспоминаний // Пролетарская революиия. - М., 1924. - № 7 (30). - С. 77. 
несмотря на то что в студенческих беспорядках не играл “никакой заметной роли”. Но для власть имущих фамилия Ульянов была одиозной с 1887 г. года попытки покушения Александра Ульянова и его сотоварищей на императора» ${ }^{13}$.

Илья Лохматый (партийный псевдоним Ильи Эренбурга) был знаком с Лениным. Они встречались в эмигрантском Париже. Эренбург об этом рассказывает в своих воспоминаниях. Встречались большевики в кафе «д’Орлеан». На втором этаже была небольшая зала, заполненная людьми, человек 30. Эренбург глядел только на Ленина. Шел 1909 год... Одет Ленин был в темный костюм, со стоячим накрахмаленным воротничком - выглядел корректно, по-видимому, как средний буржуа. Молодой Илья попросил слова и высказал возражение по обсуждаемой теме. Ленин ответил мягко, не обругал (обычно в полемике он был несдержан), а разъяснил его неправоту. Молодой человек заинтересовал Первого большевика. Он подошел к Илье и расспросил его о московских делах. Илья Лохматый к этому времени побывал в большевистской организации со своим однокашником по Первой московской гимназии Бухариным, был арестован, а теперь эмигрировал. Ленин пригласил «мальчишку» к себе на улицу Бонье. Тот испытывал робость перед сильной личностью. Открыла дверь Крупская, «сам» работал у письменного стола, чуть щуря глаза. Эренбург подробно рассказал о провале московской ученической организации, о положении в Полтаве. Вождь внимательно слушал.

Выяснилось, что Эренбург помнил адреса, по которым можно было рассылать газеты. Надежда Константиновна всё записала. Настало время обеда, и Илья хотел раскланяться, но не тут-то было: его гостеприимно накормили. Поразил Илью порядок на столе Ленина: он этого никогда не видел среди своих друзей. И еще: «Меня поразила его голова. Я вспомнил об этом пятнадцать лет спустя, когда увидел Ленина в гробу. Я долго глядел на этот изумительный череп: он заставлял думать не об анатомии, но об архитектуре» ${ }^{14}$.

По воспоминаниям Эренбурга, сходными с воспоминаниями других, В.И. Ленин говорил спокойно, без пафоса, без красноречия, слегка картавя, иногда усмехался. Его речи похожи на спираль, для разъяснения и убеждения собеседника он возвращался и повторял. Эренбург подчеркивает простоту жизни вождя, демократичность и участие в судьбе товарищей - черты, свойственные большим людям. В конце рассуждений о Ленине Эренбург приходит к выводу, что Ленину чужд культ личности.

В эмиграции с Лениным встретился очень интересный человек, в будущем сильный шахматный мастер А.Ф. Ильин-Женевский, победитель Капаб-

13. Сильвин М.А. К биографии В.И. Ленина. Из воспоминаний // Пролетарская революиия. - М., 1924. - № 7 (30). - С. 66, 73-74, 80.

14. Эренбург И. Люди, годы, жизнь. - М.: Советский писатель, 1990. - Т. 1. - С. 96. 
ланки, брат Ф.Ф. Раскольникова. Произошло это в весенний день 1914 г. Александр Фёдорович был совсем юным гимназистом, только что исключенным из гимназии Витмера и заканчивающим учебу в Швейцарии на деньги некоего благотворителя. Встреча состоялась в Женеве, куда Ленин приехал всего на один день с лекцией. Остановился он на квартире своего старого друга Вячеслава Алексеевича Карпинского. Как вспоминает Ильин, он увидел низенького, коренастого человека и в памяти всплыл облик Сократа. Растерянно протянув руку «Ильичу» для приветствия, он почувствовал в свою очередь широкое и крепкое рукопожатие. Лицо вождя расплылось в приветливой и ясной улыбке.

Молодой Саша Ильин отвечал на вопросы Ленина по поводу ареста их юношеской организации. Жена хозяина - «товарищ Ольга», она же Софья Наумовна Равич, (первая жена Г.Е. Зиновьева) пригласила всех к столу. Разговор перешел на сугубо личную тему - Ленин беспокоился о состоянии здоровья своей жены: у Надежды Константиновны была базедова болезнь. Предлагалось два пути решения проблемы: опасная операция или консервативный способ лечения. «С какой заботливостью и тревогой говорил Владимир Ильич о здоровье своей неразлучной и верной подруги». Революционер, решительно расправившийся «операционным» путем со старой Россией, в личной жизни оказался консерватором: семья Ульяновых не решилась на операцию.

Неожиданно Ленин обратил внимание, что юноша не ест мяса, и Равич быстро приготовила для него яичницу. Александр был вегетарианцем и со свойственной юности горячностью стал защищать «безубойный» способ питания. (Это было время всеобщего увлечения толстовством.) Ленин развеселился: «Ого, - сказал он, хитро улыбаясь и подмигивая Карпинским, - этак, вы, пожалуй, произведете новый раскол в партии и организуете новую фракцию большевиков-вегетарианцев». Так смеясь и пикируясь, они перешли в библиотеку, где был приготовлен послеобеденный чай ${ }^{15}$.

Тему для доклада Ленин выбрал вызывающую для космополитической среды эмигрантов, живущих в Женеве: «Национальный вопрос». По словам Ильина, различные эмигрантские национальные социалистические группировки считали преступлением всякий последовательный интернационализм. Аудитория пришла огромная: яблоку негде было упасть. Все ожидали полемики. Ленина встретили весьма прохладно, исключая кучку большевиков.

Как оратор Ленин глубоко поразил Ильина, хотя, казалось бы, его нельзя было назвать блестящим оратором. Он не обладал такими артистическими данными, как, например, местная достопримечательность - итальянский

15. Ильин-Женевский А.Ф. Один день с Лениным: Из воспоминаний «витемеровцุа». - Л. -M., 1925. - C. 11. 
анархист Бертони. Тот отличался внешностью актера-трагика, бархатным голосом и прочими атрибутами, необходимыми, чтобы обворожить женскую часть публики.

Ленин был его антиподом. Невзрачная внешность, несколько хрипловатый голос и «привычка часто причмокивать в конце фраз» - этим не покоришь зрителя. Но Ильин поймал себя на мысли, что он, слушая оратора, как бы читает книгу. «Удивительная стройность мыслей, строгая последовательность изложения и неумолимая логичность сделали то, что вся это большая и в большинстве чуждая нам аудитория, не двигаясь и почти не дыша, как зачарованная, прослушала до конца лекцию Владимира Ильича». Когда он окончил говорить, большая часть зала аплодировала ему. Но настоящее мастерство проявилось во время полемики. Он разделался с ними быстро - «это был не бой, а избиение младенцев!». Враги повержены, собрание закончено, и дружные аплодисменты сопутствовали победе логики полемиста.

Карпинские и Ильин провожают Ленина до поезда.

Последняя реплика Ильича из окна вагона:

«- Советую вам перестать быть вегетарианцем!

- Советую вам сделаться вегетарианцем! - с юношеским задором отвечаю ему я. Ленин смеется...»

Юноша запомнился Ленину, и он неоднократно справлялся у Карпинских о его житье-бытье, приглашал на отдых в Краков, но этому помешала война. А после приезда Ленина в Петроград они коротко встретились снова. Вождь не узнал его: загорелый, запыленный, в офицерских погонах - он не был похож на довоенного юнца. Ильин напомнил о себе:

«- Мы с вами видели в Женеве». Я - «витмеровец»..

«- А, вегетарианец! - воскликнул он, и веселая ласковая улыбка озарила его лицо. По-видимому, это обстоятельство всего сильнее врезалось ему в память. Милый, добрый Ильич!» ${ }^{16}$.

16. Ильин-Женевский А.Ф. Один день с Лениным: Из воспоминаний «витемеровuุ ». - Л.-М., 1925. - С. 18, 19.

Следует добавить несколько слов в адрес А.Ф. Ильина-Женевского (1894-1941). Во время Октябрьского переворота он вывел на «Штурм Зимнего» химический батальон. Фраза «милый, добрый Ильич» - неслучайная. Ф.П. Богатырчук, профессор - рентгенолог и чемпион СССР по шахматам 1927 г., а впоследствии - власовец, писал об Ильине-Женевском, как об одном из немногих известных ему коммунистов, "искренне веривших в величие своего пророка Ленина. С ним можно было даже спорить на скользкие темы и высказывать мысли, не боясь, что он донесет... У этого коммуниста было действительно человеческое лицо, но таких, как он - раз, два и обчёлся». (Богатырчук Ф.П. Мой жизненный путь к Власову и Пражскому манифесту. - СанФранциско, 1978. - С. 79.) 
Здесь уместно и мнение графа П.Н. Зубова об ораторском искусстве Ленина: «Его ораторское дарование было удивительно: каждое его слово падало, как удар молота, и проникало в черепа. Никакой погони за прикрасами, ни малейшей страстности в голосе; именно это было убедительно. Позже я имел случай сравнить способ его речи с Муссолини и Гитлером. Последний сразу начинал с истерического крика и оставался все время на этой форсированной ноте, не имея дальнейшего подъема; я никогда не мог понять, как этот человек мог влиять на слушателей, разве что они все были истериками. Прекрасноречие Муссолини могло действовать на настроение итальянцев, но по сравнению с ленинским оно не было таким же понятным. Лишь единственный европейский оратор мог сравниться с Лениным - это Черчилль» ${ }^{17}$.

К этому можно добавить свидетельство московского обывателя Н.П. Окунева, который в годы 1914-1923 вел дневник. Для историка этого времени он необыкновенно интересен важнейшими деталями быта: ценами на хлеб, сахар, рыбу, мясо, на услуги парикмахерской, баню, на одежду и обувь. В записи от 17 и 30 апреля 1918 г. читаем следующее: «Ленин всё пишет, всё говорит... Энергия этого человека действительно выдающаяся, и оратор он, как Троцкий, - безусловно, замечательный. На их выступления идут уже не одни серые большевики, пошла и “пестрая публика". Залы выступления буквально ломятся от жаждущих послушать их. Ни кадетам, ни Керенскому такого длительного и бесспорного успеха не давалось. И говорят ведь, в сущности, вещи довольно неутешительные, не хвалятся своими успехами, а вот, подите, каких оваций удостаиваются! Куда тут Шаляпин!» ${ }^{18}$.

Интересно это признание человека, относящегося отрицательно к большевизму. Автор дневника дает такую характеристику главным деятелям революции: «Все-таки надо признать, что наши настоящие властители Ленин и Троцкий - люди недюжинные. Идут к своей цели напролом, не пренебрегая никакими средствами. Если это и нахалы, то не рядовые, а своего рода гении. Керенский перед ними мелок. Он может умереть, про него лучше того, что писали весной и летом, - уже не напишут» ${ }^{19}$.

По воспоминаниям Н.К. Крупской, во время болезни вождя она читала ему «Хулио Хуренито». Книга только что (1921) вышла в издательстве «Геликон» в Берлине. Крупская писала: «Из современных вещей, помню, Ильичу понравился роман Эренбурга, описывающий войну: “Это знаешь, - Илья Лохматый (кличка Эренбурга), - торжествующе рассказывал он. - Хорошо у него вышло"». Эта оценка потрясающа - ибо в «Хулио Хуренито» достается

17. Зубов В.П. Страдные годы России: Воспоминания о Революичии [1917-1925]. München, 1968. - C. 76.

18. Окунев Н.П. Дневник москвича 1917-1920. - М., 1997. - С. 174.

19. Там же. - С. 111. 
не только новой власти, но и самому вождю. (Ясно, что в девятитомном советском собрании сочинений Эренбурга двадцать седьмая глава о Ленине выпущена.) Чего стоит само название выпущенной главы «Великий инквизитор вне легенды?» Эренбург вспоминает о своих товарищах, ныне занимающих крупные посты. Автор боится их. Почему? Его ответ: «...Не то чтоб я верил очаровательным легендам досужих жён бывших товарищей прокуроров, кои изображали большевистских главарей чем-то средним между Джеком Потрошителем и апокалипсической саранчой. Нет, я просто боялся людей, которые что-то могут сделать не только с собой, но и с другими. Этот страх перед властью я испытывал всегда... В последние же годы, увидев ряд своих приятелей, собутыльников, однокашников в роли министров, комиссаров и прочих “могущих", я понял, что страх мой вызывается не лицами, но чем-то посторонним, точнее: шапкой Мономаха, портфелем, крохотным мандатиком. Кто его знает, что он, собственно, захочет, во всяком случае (это уже безусловно), захотев - сможет» ${ }^{20}$. Отдадим должное объективности вождя, не обидевшегося на эти страницы. Причина, думается, в том, что Ульянов прекрасно знал действительность и искренне верил: иначе в России - нельзя.

Говоря об увековечивании Ленина, припомним фразу Троцкого из автобиографии: «Отношение к Ленину как к революционному вождю было подменено отношением к нему, как к главе церковной иерархии. На Красной площади был воздвигнут, при моих протестах, недостойный и оскорбительный для революционного сознания, мавзолей... Набальзамированным трупом сражались против живого Ленина и против Троцкого» ${ }^{21}$.

И еще одно свидетельство. Будущим диктатором называл Ленина посол Франции в России Морис Палеолог. 21 апреля 1917 г., на пятый день после появления лидера большевизма на Финляндском вокзале, посол записал в дневнике: «Утопист и фанатик, пророк и метафизик, чуждый представлению о невозможном и абсурдном, недоступный никакому чувству справедливости и жалости, жесткий и коварный, безумно гордый, Ленин отдает на службу своим мессианским мечтам смелую и холодную волю, неутомимую логику, необыкновенную силу убеждения и уменье повелевать... Субъект тем более опасен, что говорят, он целомудрен, умерен, аскет. В нем есть, как я представляю, черты Савонаролы, Бланки и Бакунина» ${ }^{22}$.

20. Эренбург И. Хулио Хуренито // Аврора. - Л., 1988. - № 10. - С. 37

21. Трочкий Л. Моя жизнь: Опыт автобиографии. - Берлин, 1930. - Т. ІІ. - С. 259.

22. Палеолог М. Царская Россия накануне револючии. - М., 1991. - С. 306. 